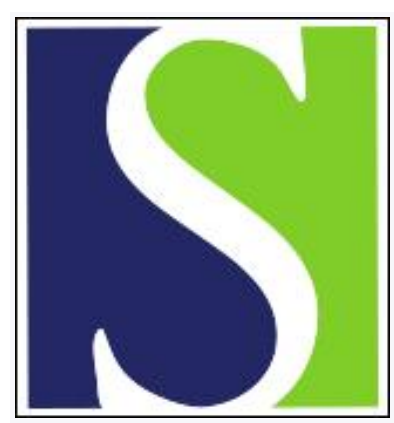

Scand J Work Environ Health 1983;9(4):303-314

https://doi.org/10.5271/sjweh.2407

Issue date: Aug 1983

Graphite pneumoconiosis. A review of etiologic and epidemiologic aspects.

by Hanoa $\mathrm{R}$

This article in PubMed: www.ncbi.nlm.nih.gov/pubmed/6314495

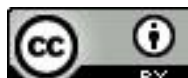




\title{
Graphite pneumoconiosis
}

\section{A review of etiologic and epidemiologic aspects}

\author{
by Rolf Hanoa, MD, MSc ${ }^{1}$
}

\begin{abstract}
HANOA R. Graphite pneumoconiosis: A review of etiologic and epidemiologic aspects. Scand $j$ work environ health 9 (1983) 303-314. Six hundred and five cases of graphite pneumoconiosis have been reported in the literature. In 39 cases the diagnosis was based on or supported by autopsy or lung biopsy results. Only 14 of the 39 cases were presented with relatively complete documentation as to details about dust exposure. Only one of these completely documented cases suggested that nearly pure graphite may cause graphite pneumoconiosis. Eleven experimental studies on animals dealt with the effect of graphite dust on various tissues, and nine with the effect on lung tissue. The three studies on the effect of pure or nearly pure graphite gave no unanimous conclusion. Five out of six studies dealing with graphite containing silica demonstrated fibrogenic effect on the lungs. Most of the 18 epidemiologic studies of workers exposed to graphite dust are invalid because they do not comply with ordinary methodologic requirements. The present state of knowledge does not exclude the possibility that analytically pure graphite may cause pneumoconiosis although the majority of the evidence indicates that pneumoconiosis is a mixed-dust type of lung reaction.
\end{abstract}

Key terms: carbon dust pneumoconiosis, graphitosis, mixed-dust pneumoconiosis, silicosis.

Graphite is either natural or synthetic. Natural graphite (plumbago) is elemental crystalline carbon with many different mineral impurities $(53,56)$. Graphite is widely distributed geographically. There are mines in Canada, Mexico, Brazil, Norway, West Germany, Italy, Czechoslovakia, Austria, the Soviet Union, Korea, China, India, Sri Lanka, Madagascar, and Zimbabwe. Natural graphite contains variable quantities of silica. Of the total silica content, that of free silica is the most interesting because of its fibrogenic potential for the lungs. Quartz is the most common crystalline type of free silica. The content of free silica varies from $11 \%$ in samples from Italy to $3.6 \%$ in samples from Sri Lanka. Natural graphite usually contains other impurities such as iron oxide, clay, mica, and other minerals. Natural graph-

\footnotetext{
1 Institute of Community Medicine, University of Troms $\emptyset$, Tromsø, Norway.
}

Reprint requests to: Prof $R$ Hanoa, Institute of Community Medicine, 9010 Åsgård sykehus, Tromsø, Norway. ite is either of the crystalline flake type or of the cryptocrystalline, amorphous type.

Synthetic or artificial graphite is crystalline carbon made by subjecting coal or petroleum coke to a temperature of $2,200-$ $3,000^{\circ} \mathrm{C}$ in an electric furnace. Synthetic graphite contains, in general, only very small quantities of free silica. But synthetic graphite may be used in workplaces where the employees are also exposed to other types of dust. Both the mining and curing of natural graphite and the production of synthetic graphite have been relatively dusty processes.

Graphite has many useful properties, and for the manufacture of many products it has few or sometimes no substitutes. Natural graphite is used to make blast furnace hearths, as well as linings and crucibles and ladles for the chemical and nonferrous metallurgical industries (53). Natural graphite is used in foundry facings. In steel and cast iron manufacturing natural graphite increases the hardness and strength of the metal. Amorphous natural graphite is used in pencils. Both 
natural and synthetic graphite may be used as a component or alone as a lubricant. Neutron moderators in atomic reactors can be produced from synthetic graphite. Synthetic graphite is also used in the manufacture of carbon electrodes. Natural graphite was also used in the past in electrotyping.

It is important not to confuse graphite with other carbon substances encountered in occupational medicine, eg, coal, lamp black, and carbon black (53). Lamp black is an amorphous carbon used mainly as a paint pigment and an oil-absorption agent. It contains no quartz. Carbon black is hard, brilliant and mainly crystalline. It is used in rubber, plastics, printing inks, paints, and enamels and in the manufacture of carbon electrodes and carbon paper. Pneumoconiosis due to carbon black has been reported by, among others, Miller \& Ramsden (44).

In this review graphite pneumoconiosis is defined as pneumoconiosis in workers exposed to graphite dust at the workplace. The term graphite pneumoconiosis does not imply that carbon is the only or main etiological factor in the pneumoconiosis. The term pure graphite pneumoconiosis (or graphitosis), used by some authors, is applied when the authors claim the pneumoconiosis is caused solely or mainly by carbon. Mixed-dust pneumoconiosis applies to pneumoconiosis caused by congruent exposure to crystalline silica and other dusts such as carbon. Silicosis is defined as a pneumoconiosis which is primarily due to free silica. The term should not be used for "coal pneumoconiosis and other types of pneumoconiosis the features of which are entirely different even if free silica may play some part in their pathogenesis [p 134]" (53).

Koopmann (37) was the first to publish a case report of graphite pneumoconiosis. From the autopsy he described the condition as extensive pneumoconiosis with cavities resulting from necrosis; chronic interstitial pneumonia, peribronchiolitis, and periarteritis nodosa. The cavities were not caused by tuberculosis. There had been no clinical symptoms. The pneumoconiosis was not the cause of death. Koopmann presented his case as if the pneumoconiosis was caused by carbon alone.

Lochtkemper \& Teleky (41) were the first authors to point out the role of quartz in the etiology of pneumoconiosis in workers exposed to graphite dust. They did not consider carbon to be the only etiological factor in their three reported cases. They criticized Hollmann (29) for disregarding the quartz impurities in coal and graphite. Hollmann published three cases of pneumoconiosis among workers exposed to coal dust or coal and graphite dust. He maintained that the men had been exposed to pure carbon dust, although no dust analyses had been done.

The first published cases of graphite pneumoconiosis which included clinical, radiographic, and autopsy details were reported by Faulkner (16), and by Dunner (9) and Harding \& Oliver (26) in cooperation. The main features of the case of Dunner/Harding \& Oliver were as follows: $\mathrm{HD}$, aged 67 , had worked in a graphite mill grinding Korean graphite (natural graphite containing free silica) for 19 years. He had never had another job with dust exposure. Eight years after leaving the graphite mill he lost weight and developed marked dyspnea. He had very little sputum and not much cough. There was dullness to percussion in the right subclavicular region. A radiograph of his chest showed a massive homogeneous opacity in the right upper zone, a small rounded opacity overlying the hilum of the right lung, a homogeneous opacity of less density in the left upper zone, a rounded opacity the size of a golf ball overlying the left hilum, and a fine mottling in the midzones of both lungs. Autopsy showed adhesions between the upper parts of each lung and the chest wall. Black pigment, similar to graphite, was seen in the pleural lining of the chest wall and throughout the lungs, which were jet black. On palpation there was a firm fibrous mass in each of the lobes of the lungs. In the center of each mass there was necrosis and a cavity filled with black semi-solid material. There were also three fibrotic nodules. No evidence of tuberculosis was present. Histological examination revealed widespread focal emphysema, which was somewhat masked by edema, some purulent bronchitis, and bronchopneumonia. There were very many small areas of linear and radial fibrosis, but nothing resembling the classical whorled silicotic lesion.

Since 1924 several reports of cases of 
graphite pneumoconiosis have appeared, the last case reports coming from Norway (25) and Japan (30) (table 1). Various views on the etiology of graphite pneumoconiosis have been presented. The two most common points of view have been (i) that the pneumoconiosis is caused solely or mainly by carbon and (ii) that graphite pneumoconiosis is a mixed-dust pneumoconiosis. The views of the different authors are presented in table 1 .

Many authors have been preoccupied with the resemblance between graphite pneumoconiosis and coal worker's pneumoconiosis. Both have a simple and a progressive massive stage. The location in the lung zones may be the same. Both natural graphite pneumoconiosis and coal worker's pneumoconiosis may show eggshell calcification and clubbing. Radiographs are similar for the two conditions, and there are no principal differences between the histological lesions of the two conditions, which are quite different from nodular silicosis. The occupational history is essential to differentiate between graphite pneumoconiosis and coal worker's pneumoconiosis.

The relatively large quantity of scientific articles about graphite pneumoconiosis may reflect the expectation that these studies would throw light upon the etiology and pathogenesis of coal worker's pneumoconiosis as well. The role of free silica in the etiology and pathogenesis of coal worker's pneumoconiosis is disputed (53). This dispute has a practical bearing upon the choice of standards for the prevention of coal worker's pneumoconiosis. Studies by Jacobsen (32) suggest that quartz exposure of less than $10 \%$ of coal mine dust does not affect the probability of developing pneumoconiosis. The incidence of simple coal worker's pneumoconiosis is chiefly related to the mass of respirable dust over the period of exposure (72). However experimental studies on animals have not produced unanimous results as to the effect of coal and quartz in the lungs (53).

One would expect pure coal dust (without free silica) and pure graphite dust to act in the same way on lung tissue. If one could unambiguously show that pure graphite dust clinically or experimentally might cause pneumoconiosis, the result would have a bearing on the coal pneumoconiosis dispute too.

\section{Experimental studies of the effect of graphite dust on various tissues}

Eleven experimental studies have been done to determine whether graphite dust is fibrogenic and could cause pneumoconiosis $(1,2,8,15,26,49,50,52,57,58,61$, $64)$. Most of the experimental studies have used rats. In six of the studies the animals have been exposed to natural graphite containing some silica $(2,15,26,57,58,61)$. Synthetic graphite has been used in four studies $(2,52,57,64)$. Two investigations have used both natural and synthetic graphite $(2,57)$. In three studies the type of graphite (and in two of them the silica content) was not specified $(1,8,49,50)$.

In most of the experiments the animals were exposed to graphite applied intratracheally or by inhalation. The results of the 11 experiments are heterogeneous. There is no unanimous conclusion as to whether pure or nearly pure graphite is fibrogenic in the lungs. Bovet (2) demonstrated that pure graphite causes slight pulmonary fibrosis. Pendergrass et al (57) showed that nearly pure graphite was inert. Drowatzky (8) found no significant silicosis as a result of exposure to graphite with less than $1 \%$ free silica. Graphite containing silica was considered to be fibrogenic in the lungs of animals by Harding \& Oliver (26), Ray et al (61), Ottowicz \& Paradowski (52), Pendergrass et al (57), and Drowatzky (8). Engelmann (15) found no such effect. After all, the 11 experiments do not leave much certainty as to the etiology and pathogenesis of graphite pneumoconiosis. The results suggest however that graphite containing silica is fibrogenic in lung tissue.

\section{Clinical reports of graphite pneumoconiosis}

Approximately 605 cases of graphite pneumoconiosis are reported in the literature. The term "approximately" is used because in a few instances two different reports refer to the same cases. When allowance is made for this fact, the true number of reported cases would be about 540 . Some reports are presented in a way that makes it difficult to determine exactly how many cases are reported. The numbers of reported cases are presented in table 1 with 
Table 1. Cases of graphite pneumoconiosis reported through 1982.

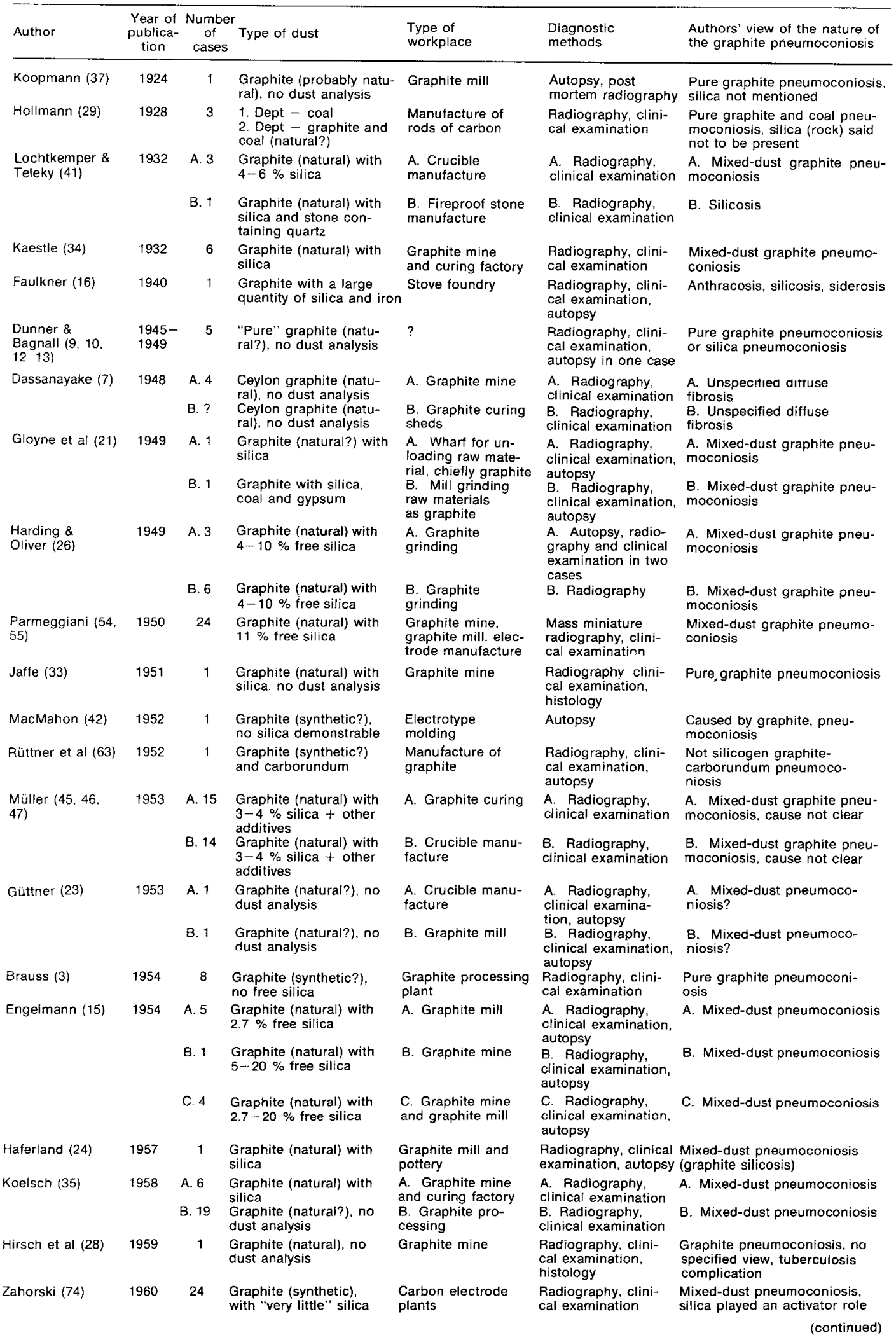


Table 1. (Continued)

\begin{tabular}{|c|c|c|c|c|c|c|}
\hline Author & $\begin{array}{l}\text { Year of } \\
\text { publica- } \\
\text { tion }\end{array}$ & $\begin{array}{l}\text { Number } \\
\text { of } \\
\text { cases }\end{array}$ & Type of dust & $\begin{array}{l}\text { Type of } \\
\text { workplace }\end{array}$ & $\begin{array}{l}\text { Diagnostic } \\
\text { methods }\end{array}$ & $\begin{array}{l}\text { Authors' view of the nature of } \\
\text { the graphite pneumoconiosis }\end{array}$ \\
\hline Lister (39) & 1961 & 1 & $\begin{array}{l}\text { Graphite (synthetic) with } \\
0.02 \% \text { free silica }\end{array}$ & $\begin{array}{l}\text { Lathe operator in } \\
\text { small factory } \\
\text { producing graph- } \\
\text { ite bars }\end{array}$ & $\begin{array}{l}\text { Radiography, clini- } \\
\text { cal examination }\end{array}$ & $\begin{array}{l}\text { "Nearly pure" graphite pneu- } \\
\text { maconiosis }\end{array}$ \\
\hline $\begin{array}{l}\text { Sklensky \& } \\
\text { Berka }(67)\end{array}$ & 1963 & 4 & $\begin{array}{l}\text { Graphite (natural) with } \\
5 \% \text { free silica }\end{array}$ & $\begin{array}{l}\text { Graphite mine and } \\
\text { drying station }\end{array}$ & $\begin{array}{l}\text { Radiography, clini- } \\
\text { cal examination }\end{array}$ & $\begin{array}{l}\text { Not graphitosis but graphite } \\
\text { silicosis, mixed-dust pneu- } \\
\text { moconiosis }\end{array}$ \\
\hline Okutani et al (48) & 1963 & 112 & $\begin{array}{l}\text { Graphite with } 0.1 \% \text { free } \\
\text { silica }\end{array}$ & $\begin{array}{l}\text { Carbon electrode } \\
\text { manufacture }\end{array}$ & $\begin{array}{l}\text { Radiography, clini- } \\
\text { cal examination, } \\
\text { autopsy ( } 2 \text { cases) }\end{array}$ & Graphite pneumoconiosis \\
\hline Coscia et al $(6)$ & 1963 & 38 & $\begin{array}{l}\text { Graphite (natural) with } \\
\text { free silica }\end{array}$ & Graphite mine & $\begin{array}{l}\text { Radiography, clini- } \\
\text { cal examination }\end{array}$ & $\begin{array}{l}\text { Pneumoconiosis, no expressed } \\
\text { opinion }\end{array}$ \\
\hline $\begin{array}{l}\text { Casalone \& } \\
\text { Rasetti (5) }\end{array}$ & 1963 & 9 & $\begin{array}{l}\text { Graphite (natural?) with } \\
12 \% \text { free silica }\end{array}$ & Pipe manufacture & $\begin{array}{l}\text { Radiography, clini- } \\
\text { cal examination }\end{array}$ & Silicosis \\
\hline Gaido et al (19) & 1963 & 36 & $\begin{array}{l}\text { Graphite (natural) with } \\
20-30 \% \text { silica }\end{array}$ & Graphite mine & $\begin{array}{l}\text { Radiography, clini- } \\
\text { cal examination }\end{array}$ & Silicosis \\
\hline $\begin{array}{l}\text { Koschnitsky et al } \\
\text { (38) }\end{array}$ & 1964 & 15 & $\begin{array}{l}\text { Graphite (natural) with } \\
\text { silica }\end{array}$ & $\begin{array}{l}\text { Graphite mine and } \\
\text { curing factory }\end{array}$ & $\begin{array}{l}\text { Radiography, clini- } \\
\text { cal examination }\end{array}$ & Silicosis \\
\hline $\begin{array}{l}\text { Gaensler } \\
\text { et al }(18)\end{array}$ & 1966 & 4 & $\begin{array}{l}\text { Graphite (natural) with } \\
\text { silica }\end{array}$ & $\begin{array}{l}\text { Electrotype molding } \\
\text { in printing industry }\end{array}$ & $\begin{array}{l}\text { Clinical examina- } \\
\text { tion, radiography ( } 3 \\
\text { cases), autopsy } \\
\text { ( } 3 \text { cases) }\end{array}$ & $\begin{array}{l}\text { Progressive massive fibrosis - } \\
\text { not silicosis, but silica played } \\
\text { "a small role, if any" }\end{array}$ \\
\hline $\begin{array}{l}\text { Radionov } \\
\text { et al (59) }\end{array}$ & 1967 & 7 & $\begin{array}{l}\text { Graphite (natural) with } \\
\text { silica }\end{array}$ & $\begin{array}{l}\text { Graphite mine and } \\
\text { curing factory }\end{array}$ & $\begin{array}{l}\text { No details } \\
\text { given }\end{array}$ & Silicosis \\
\hline $\begin{array}{l}\text { Pendergrass } \\
\text { et al }(56,57)\end{array}$ & 1967 & $\begin{array}{l}V \\
g \\
\text { to } \\
\text { tc }\end{array}$ & $\begin{array}{l}\text { Various types of natural } \\
\text { graphite, many exposed } \\
\text { to other types of dust } \\
\text { too }\end{array}$ & $\begin{array}{l}\text { A. } 7 \text { : various parts } \\
\text { of graphite industry } \\
\text { B. 4: graphite plants } \\
\text { in Pennsylvania }\end{array}$ & $\begin{array}{l}\text { A + B. Radiography, } \\
\text { clinical examination, } \\
\text { biopsy ( } 2 \text { cases) } \\
\text { autopsy ( } 3 \text { cases) }\end{array}$ & $\begin{array}{l}\text { A. + B. Mixed-dust pneumo- } \\
\text { coniosis "largely the result } \\
\text { of free crystalline silica" }\end{array}$ \\
\hline Town $(68)$ & 1968 & 1 & $\begin{array}{l}\text { Graphite (natural) with } \\
\text { silica }\end{array}$ & $\begin{array}{l}\text { Graphite mine and } \\
\text { mill }\end{array}$ & $\begin{array}{l}\text { Radiography, clini- } \\
\text { cal examination, } \\
\text { autopsy }\end{array}$ & Graphite pneumoconiosis \\
\hline $\begin{array}{l}\text { Ranasinha \& } \\
\text { Uragoda }(60)\end{array}$ & 1972 & 78 & $\begin{array}{l}\text { Graphite (natural) with } \\
\text { free silica }\end{array}$ & Graphite mine & $\begin{array}{l}70-m m \text { radiography. } \\
\text { clinical examina- } \\
\text { tion of } 73 \text { cases }\end{array}$ & $\begin{array}{l}\text { Mixed-dust pneumoconiosis, } \\
\text { not a silicosis, not a pure } \\
\text { carbon pneumoconiosis }\end{array}$ \\
\hline $\begin{array}{l}\text { Lister \& } \\
\text { Wimborne (40) }\end{array}$ & 1972 & 1 & $\begin{array}{l}\text { Graphite (synthetic) } \\
\text { with } 0.02 \% \text { free silica }\end{array}$ & $\begin{array}{l}\text { Lathe operator in a } \\
\text { small factory pro- } \\
\text { ducing graphite bars }\end{array}$ & $\begin{array}{l}\text { Radiography, clini- } \\
\text { cal examination, } \\
\text { autopsy }\end{array}$ & $\begin{array}{l}\text { Nearly pure graphite preu- } \\
\text { moconiosis }\end{array}$ \\
\hline Uragoda (69) & 1972 & 3 & $\begin{array}{l}\text { Graphite (natural) with } \\
\text { free silica }\end{array}$ & Graphite mine & $\begin{array}{l}\text { Radiography, clini- } \\
\text { cal examination }\end{array}$ & Tuberculosis-pneumoconiosis \\
\hline Uragoda $(70)$ & 1972 & 1 & $\begin{array}{l}\text { Graphite (natural) with } \\
\text { free silica }\end{array}$ & Graphite mine & $\begin{array}{l}\text { 70-mm radiography, } \\
\text { clinical examination }\end{array}$ & $\begin{array}{l}\text { Graphite pneumoconiosis } \\
\text { complicated by tuberculosis }\end{array}$ \\
\hline Einbrodt (14) & 1973 & 1 & Graphite with free silica & Graphite mill & Autopsy & $\begin{array}{l}\text { Anthraco-silicosis with } \\
\text { lymphnode tuberculosis }\end{array}$ \\
\hline $\begin{array}{l}\text { Koizumi et al } \\
\text { (36) }\end{array}$ & 1974 & 1 & $\begin{array}{l}\text { Graphite (not specified) } \\
\text { with silica }\end{array}$ & $\begin{array}{l}\text { Milling graphite, a } \\
\text { factory producing } \\
\text { graphite powder for } \\
\text { blackboards }\end{array}$ & $\begin{array}{l}\text { Radiography, clini- } \\
\text { cal examination }\end{array}$ & $\begin{array}{l}\text { Mixed-dust pneumoconiosis } \\
\text { due to graphite and silica }\end{array}$ \\
\hline $\begin{array}{l}\text { Zahorski } \\
\text { et al (75) }\end{array}$ & 1975 & 86 & $\begin{array}{l}\text { Graphite (artificial) with } \\
\text { silica }\end{array}$ & $\begin{array}{l}\text { Coal electrode pro- } \\
\text { duction, milling } \\
\text { plant }\end{array}$ & $\begin{array}{l}\text { Radiography, clini- } \\
\text { cal examination }\end{array}$ & $\begin{array}{l}\text { Mixed-dust pneumoconiosis, } \\
\text { like coal worker's pneumoco- } \\
\text { niosis }\end{array}$ \\
\hline $\begin{array}{l}\text { Uragoda \& } \\
\text { Rajendra (71) }\end{array}$ & 1975 & 32 & $\begin{array}{l}\text { Graphite (natural) with } \\
\text { low silica content }\end{array}$ & Graphite curing & $\begin{array}{l}\text { hadiography, clini- } \\
\text { cal examination }\end{array}$ & $\begin{array}{l}\text { Mixed-dust pneumoconiosis } \\
\text { with graphite and silica as } \\
\text { causes }\end{array}$ \\
\hline Hanoa (25) & 1981 & 1 & $\begin{array}{l}\text { Graphite (natural) with } \\
10 \% \text { silica }\end{array}$ & $\begin{array}{l}\text { Graphite mine and } \\
\text { curing }\end{array}$ & $\begin{array}{l}100-x-100-\mathrm{mm} \\
\text { mass radiography, } \\
\text { clinical examination }\end{array}$ & Mixed-dust pneumoconiosis \\
\hline $\begin{array}{l}\text { Inoue } \\
\text { et al (30) }\end{array}$ & 1982 & 1 & Graphite, not specified & Not specified & $\begin{array}{l}\text { Radiography, clini- } \\
\text { cal examination } \\
\text { autopsy }\end{array}$ & $\begin{array}{l}\text { Graphite lung with tuberculous } \\
\text { granulomas }\end{array}$ \\
\hline
\end{tabular}

the surname of the author, the year of publication, the type of graphite, type of workplace, diagnostic methods, and each author's opinion of the etiology of pneumoconiosis.

Many authors have provided only scanty data with regard to the type of graphite concerned (natural or synthetic), the silica content of dust, and the exposure of their cases to other types of dust. According to the data given by the authors, the
605 cases can be distributed as shown in table 2.

For 167 reported cases there is no information as to whether the cases have been exposed to natural or synthetic graphite; 326 cases are reported as being exposed to natural graphite, and 112 are reported as exposed to synthetic graphite.

The 605 cases worked in a wide range of different workplaces. Table 3 shows the distribution of cases by different types 
Table 2. Reported cases of graphite pneumoconiosis according to type of graphite.

\begin{tabular}{lc}
\hline Type of graphite & $\begin{array}{c}\text { Number } \\
\text { of } \\
\text { cases }\end{array}$ \\
\hline Graphite, no details & 32 \\
Graphite, no details, but with silica & 126 \\
Graphite, no details, but without silica & 9 \\
Graphite with silica & 310 \\
$\quad$ Natural & 112 \\
Synthetic & - \\
Graphite without silica & - \\
$\quad$ Synthetic & 16 \\
No information on silica content & - \\
$\quad$ Satural & 605 \\
\hline Total & \\
\hline
\end{tabular}

Table 3. Reported cases of graphite pneumoconiosis according to type of workplace.

\begin{tabular}{lc}
\hline Type of workplace & $\begin{array}{c}\text { Number } \\
\text { of } \\
\text { cases }\end{array}$ \\
\hline Mine & 163 \\
Mine and mill (or curing) & 44 \\
Mill or curing only & 66 \\
Graphite manufacture unspecified & 40 \\
Manufacture of crucibles, electrodes, and & 261 \\
carbon bars; electrotyping; foundries; etc & 31 \\
No information or unspecified or more & 605 \\
than one type & \\
\hline Total &
\end{tabular}

Table 4. Clinical methods applied to establish the diagnosis of graphite pneumoconiosis.

\begin{tabular}{lr}
\hline Clinical methods & $\begin{array}{c}\text { Number } \\
\text { of } \\
\text { cases }\end{array}$ \\
\hline Clinical examination, radiography & 449 \\
Clinical examination, radiography, biopsy & 4 \\
Clinical examination, radiography, autopsy & 30 \\
Radiography alone & 6 \\
Autopsy alone or autopsy plus clinical & 5 \\
examination & 99 \\
Mass radiography, clinical examination & 12 \\
Other combinations or no information & 605 \\
\hline Total &
\end{tabular}

Table 5. Authors' view of the etiology of graphite pneumoconiosis.

\begin{tabular}{lc}
\hline Etiology & $\begin{array}{c}\text { Number } \\
\text { of } \\
\text { authors }\end{array}$ \\
\hline Pure graphite pneumoconiosis & 6 \\
Nearly pure graphite pneumoconiosis & 2 \\
Mixed-dust pneumoconiosis & 20 \\
Silicosis & 5 \\
Not specified or other views & 8 \\
\hline Total & 41 \\
\hline
\end{tabular}

of workplace.

A large proportion of cases had been exposed to graphite dust during their work in graphite mines. Nearly half of the cases were engaged in industries using graphite in the production process or in the final product.

Most reported cases of graphite pneumoconiosis were diagnosed on the basis of a clinical examination and chest radiograph (table 4). In only 39 cases was the diagnosis based on or supported by autopsy, or lung biopsy during life. In 14 of these cases $(15,26,40)$ details were presented as to the type of graphite dust and content of silica. The 10 cases of Engelmann (15) involved exposure to natural graphite with a free silica content of at least $2.7 \%$. The cases of Harding \& Oliver (26) had exposure to natural graphite dust containing 4-10\% free silica. The case of Lister \& Wimborne (40) had exposure to synthetic graphite containing less than $0.02 \%$ free silica. These 14 cases are the only completely documented cases of graphite pneumoconiosis in the literature. In 25 of the 39 cases with autopsy or lung biopsy there was no information as to the type of graphite and/or the content of silica. For these 25 cases a detailed description of the dust and the exposure would have been particularly valuable.

\section{Etiology of graphite pneumoconiosis}

Nearly all the authors present their opinion about the etiology of graphite pneumoconiosis. In table 5 the opinions of various authors are distributed in different categories. A few authors are counted more than once because they have published more than one study with case reports. But different reports based on the same cases and written by the same author are only counted once.

One-half of the authors looked at graphite pneumoconiosis as a mixed-dust pneumoconiosis, ie, caused by both silica and graphite dust. Eight authors consider graphite alone, or above all other agents, as the cause of graphite pneumoconiosis $(3,18,29,33,37,39,40,48,68)$.

Koopmann (37), Hollmann (29), Jaffe (33), and Town (68) did not present any 
analysis of the graphite dust in the workplace. Jaffe (33) and Town (68) reported cases with exposure to natural graphite. Gaensler et al (18) presented cases with exposure to natural graphite. Their data suggest a very low content of free silica, but the analysis of dust in the workplace was not complete. Brauss (3) presented cases with exposure to graphite dust with no demonstrable free silica. In the study of Okutani et al (48) graphite (unspecified) dust in the workplace contained $0.1 \%$ free silica. The case presented by Lister (39) and later by Lister \& Wimborne (40) involved exposure to synthetic graphite dust with $0.02 \%$ free silica. MacMahon (42) presented a case of exposure to graphite (unspecified) with no demonstrable silica; the author expressed no definite opinion as to the etiology of the pneumoconiosis. None of the authors giving details about the content of free silica specified whether the content referred to the respirable dust or to the total dust.

The only reports which suggest that pure graphite may cause graphite pneumoconiosis are those of Brauss (3) and MacMahon (42). The only reports which suggest that nearly pure graphite may cause graphite pneumoconiosis are those of Okutani et al (48), Lister (39), and Lister \& Wimborne (40).

\section{Epidemiologic studies of workers exposed to graphite}

Table 6 gives a survey of epidemiologic studies. There are 20 reports of 18 such studies of workers exposed to graphite dust. Two of the reports present investigations which have already been presented in earlier reports. Nine of the studies describe employees in mines, or in a mine and curing factory combined.

Sixteen of the 18 studies were crosssectional. One investigation by Zahorski et al (75) seems to be a cohort study, and another study by Zahorski (74) a period prevalence investigation (but this is not made clear by the author). There are no case-referent studies. Only the two investigations by Gaido et al (19) and Ranasinha \& Uragoda (60) used reference groups. Only the studies by Hollmann (29), Bruusgaard
(4), Parmeggiani (54, 55). Müller (45, 46, 47), Koelsch (35), Uragoda \& Rajendra (71), and Hanoa (25) gave details about the population size and sampling methods.

Hanoa (25) did his study in the same Norwegian graphite mine as Bruusgaard (4) did 47 years earlier. In the 1930 s this little mining community was very isolated, only accessible by sea, and Bruusgaard had no facilities for radiographic examination there.

Table 6 presents the investigation methods of the 18 epidemiologic studies. Radiographic examination would be sufficient to sort out the possible cases of pneumoconiosis. Clinical examination and history would be necessary to establish the diagnosis and the type of pneumoconiosis. Numerous different classifications of pneumoconiosis are applied in the different studies. The present classification of the International Labour Office (ILO) (31) was not applied in any of the 18 studies.

The prevalence rates of the investigations vary greatly. The highest prevalence rates were those of Coscia et al (6) - 73\% and Gaido et al (19) - $72 \%$. With two exceptions the studies of employees in the graphite industry in Europe did not show a very wide prevalence range, eg, there were Kaestle (34) with $5 \%$, Parmeggiani $(54,55)$ with $6 \%$, Sklensky \& Berka $(67)$ with $7 \%$, Koschnitsky et al (38) with $8 \%$, Radionov et al (59) with $4 \%$, and Hanoa (25) with $1 \%$. The last study comprised all the employees in the mining company.

The variation in prevalence rates can partly be explained by the differences in (i) the definition of the population at risk, (ii) the sampling methods, (iii) the methods and standards of examination, (iv) the classification of pneumoconioses. Because of these many differences it would not be meaningful to relate reported prevalence rates to varying silica content in the graphite dust.

The differences in prevalence rates may of course also reflect real variation in the prevalence of graphite pneumoconiosis. In 12 out of the 18 studies the minimum number of years of exposure to develop graphite pneumoconiosis is stated. The lowest minimum is stated by Müller (47) - 5.5 years of exposure. Ranasinha \& Uragoda (60) found that the average 
Table 6. Epidemiologic studies of workers exposed to graphite.

\begin{tabular}{|c|c|c|c|c|}
\hline Author & Type of workplace & $\begin{array}{l}\text { Size of } \\
\text { popu- } \\
\text { lation }\end{array}$ & Investigation methods & $\begin{array}{c}\text { Prevalence } \\
\text { (cases } \\
\text { per 100) }\end{array}$ \\
\hline Hollmann (29) & Manufacture of carbon rods & 33 & $\begin{array}{l}\text { Clinical examination, radi- } \\
\text { ography }\end{array}$ & 9 \\
\hline Kaestle (34) & Graphite mining and curing & 120 & $\begin{array}{l}\text { Clinical examination, radi- } \\
\text { ography }\end{array}$ & 5 \\
\hline Bruusgaard (4) & Graphite mining and curing & 83 & Clinical examination & - \\
\hline Dassanayake (7) & Graphite mining and curing & $\begin{array}{l}\text { A. } 50 \\
\text { B. } 62\end{array}$ & $\begin{array}{l}\text { Clinical examination, radi- } \\
\text { ography } \\
\text { Clinical examination, radi- } \\
\text { ography }\end{array}$ & $\begin{array}{l}8 \\
?\end{array}$ \\
\hline Parmeggiani $(54,55)$ & $\begin{array}{l}\text { Graphite mine, mill, electrode } \\
\text { manufacture }\end{array}$ & 415 & $\begin{array}{l}\text { Clinical examination, mass } \\
\text { miniature radiography }\end{array}$ & 6 \\
\hline Müller $(45,46,47)$ & $\begin{array}{l}\text { Graphite mill, crucible manu- } \\
\text { facture }\end{array}$ & $\begin{array}{l}\text { A. } 53 \\
\text { B. } 71\end{array}$ & $\begin{array}{l}\text { Clinical examination, radi- } \\
\text { ography } \\
\text { Clinical examination, radi- } \\
\text { ography }\end{array}$ & $\begin{array}{l}28 \\
20\end{array}$ \\
\hline Koelsch (35) & $\begin{array}{l}\text { Graphite processing plant } \\
\text { A. See Kaestle (34) }\end{array}$ & 60 & $\begin{array}{l}\text { Clinical examination?, radi- } \\
\text { ography }\end{array}$ & 13 \\
\hline & B. Graphite processing & 550 & $\begin{array}{l}\text { Clinical examination, radi- } \\
\text { ography }\end{array}$ & 3 \\
\hline Zahorski (74) & Carbon electrode plant & 52 & $\begin{array}{l}\text { Clinical examination, radi- } \\
\text { ography }\end{array}$ & $\begin{array}{l}\text { Period } \\
\text { prevalence } \\
\text { study? }\end{array}$ \\
\hline Coscia et al (6) & Graphite mine & 52 & $\begin{array}{l}\text { Clinical examination, radi- } \\
\text { ography }\end{array}$ & 73 \\
\hline $\begin{array}{l}\text { Casalone \& } \\
\text { Rasetti (5) }\end{array}$ & Pipe manufacture & 193 & $\begin{array}{l}\text { Clinical examination, radi- } \\
\text { ography }\end{array}$ & 5 \\
\hline Gaido et al (19) & $\begin{array}{l}\text { Graphite mine [see also Coscia } \\
\text { et al }(6) \text { ] }\end{array}$ & $\begin{array}{l}50 \\
+ \text { refer- } \\
\text { ence } \\
\text { group }\end{array}$ & $\begin{array}{l}\text { Clinical examination, radi- } \\
\text { ography }\end{array}$ & 72 \\
\hline Okutani et al (48) & Carbon electrode manufacture & 256 & $\begin{array}{l}\text { Clinical examination, radi- } \\
\text { ography or mass radi- } \\
\text { ography? }\end{array}$ & 44 \\
\hline Sklensky \& Berka (67) & Graphite mine and drying station & 57 & $\begin{array}{l}\text { Clinical examination, radi- } \\
\text { ography }\end{array}$ & 7 \\
\hline Koschnitsky et al (38) & Graphite mining and curing & 188 & $\begin{array}{l}\text { Clinical examination, radioscopy, } \\
\text { radiography in } 33 \text { suspected cases }\end{array}$ & 8 \\
\hline Radionov et al (59) & $\begin{array}{l}\text { Graphite mining and curing [see } \\
\text { also Koschnitsky et al (38)] }\end{array}$ & 188 & No details given & 4 \\
\hline $\begin{array}{l}\text { Ranasinha \& } \\
\text { Uragoda }(60)\end{array}$ & Graphite mine & $\begin{array}{l}344 \\
+ \text { refer- } \\
\text { ence } \\
\text { group }\end{array}$ & $\begin{array}{l}70-\mathrm{mm} \text { mass radiography, clini- } \\
\text { cal examination of those radi- } \\
\text { ographically positive }\end{array}$ & 23 \\
\hline $\begin{array}{l}\text { Uragoda \& } \\
\text { Rajendra (71) }\end{array}$ & Graphite curing & 125 & $\begin{array}{l}\text { Clinical examination, radi- } \\
\text { ography }\end{array}$ & 26 \\
\hline Zahorski et al (75) & Synthetic graphite electrodes & 290 & $\begin{array}{l}\text { Clinical examination, radi- } \\
\text { ography }\end{array}$ & $\begin{array}{l}\text { Cohort } \\
\text { study? }\end{array}$ \\
\hline Hanoa (25) & Graphite mining and curing & 105 & $\begin{array}{l}\text { Clinical examination, } 100-x-100- \\
\text { mm mass radiography }\end{array}$ & 1 \\
\hline
\end{tabular}

number of years of exposure to develop radiographic abnormalities was 21 .

\section{Other reports on the effect of graphite dust}

The case reports of graphite pneumoconiosis published in the 1940 s served as a background for editorials in the British
Medical Journal (77) and the Lancet (76). Heppleston (27) and Dunner (11) contributed to the discussion of the etiology of graphite pneumoconiosis in letters to the editor of the Lancet. McCord (43) published, in 1949, a review article about graphite as a source of dusty lung disease. No case was presented. Glauser \& Rüttner (20) described graphite bodies in the lung tissue of a worker exposed to graphite 
dust. The same topic was dealt with in another article by Rüttner (62). Schkavro (65) described a workplace with heavy graphite dust exposure in the Soviet Union. No case was reported.

\section{Discussion}

An essential issue in graphite pneumoconiosis research has been the question of etiology. Eight authors consider graphite alone, or above all other agents, as the cause of graphite pneumoconiosis. But only three, Brauss (3), Okutani et al (48), Lister (39)/Lister \& Wimborne (40), suggest that pure or nearly pure graphite may cause graphite pneumoconiosis. In addition MacMahon (42), who expressed no definite opinion about the etiology, has presented a report which suggests that pure graphite may cause pneumoconiosis. Okutani et al, Lister \& Wimborne, and MacMahon have presented cases with diagnoses supported by autopsy. These reports are suggestive although they do not specify the composition of respirable graphite dust in the workplace.

Parkes (53) summarized some reports of carbon pneumoconiosis where "quartz was either absent or of negligible amount that is less than 1 per cent [p 191]." $\mathrm{He}$ mentioned the following five reports of graphite pneumoconiosis caused by "artificial or quartz-free graphite": Rüttner et al (63), Zahorski (74), Gaensler et al (18), Pendergrass et al $(56,57)$, and Town (68).

Do these five reports demonstrate what Parkes supposes them to? Rüttner et al (63) dealt with a case exposed to both graphite without quartz and carborundum dust. Zahorski (74) presented cases with exposure to synthetic graphite containing "very little" silica. Gaensler et al (18) presented cases involving virtual exposure to natural graphite with an unsatisfactorily specified content of free silica. Pendergrass et al $(56,57)$ presented cases with exposure to various, natural types of graphite dust; many involved exposure to other types of dust too. Town (68) dealt with a case of exposure to natural graphite with an unspecified content of free silica. I am afraid that out of these five reports only Zahorski's demonstrates the effect of "artificial or quartz-free graphite."
Parkes (53) referred to reports supposed to show that other types of pure or nearly pure carbon may cause pneumoconiosis; he referred to Gough's report (22) on coal trimmers working with washed clean coal, the reports of Miller \& Ramsden (44) and Lister \& Wimborne (40) on workers exposed to carbon black, and the reports of Otto \& Einbrodt (51), Watson et al (73), and Foà et al (17) on workers exposed to carbon mixtures used in electrode manufacturing. In four of these reports traces of silica or quartz are mentioned $(17,22$, $51,73)$. In one report tuberculosis was mentioned as a partial cause of fibrosis (44). Only two reports presented any analysis of the dust in the workplace $(17,40)$.

In relation to the discussion of the etiology of graphite pneumoconiosis it is valuable if the diagnosis is supported by autopsy or lung biopsy during life. In only 39 of the reported 605 cases the diagnosis was based on or supported by autopsy or lung biopsy. Only 14 of these 39 cases were presented with relatively detailed documentation as to dust exposure [Engelmann (15), Harding \& Oliver (26), Lister \& Wimborne (40)]. Only one case suggests that nearly pure graphite may cause graphite pneumoconiosis (40).

Some experimental studies on animals have been done to illuminate the effect of graphite dust. Nine of the 11 studies dealt with the effect of graphite dust on lung tissue. When one considers all the experiments together, they do not leave much certainty as to the effect of graphite dust. The results suggest however that graphite dust containing free silica is fibrogenic in lung tissue. Still, the experiments have succeeded in bringing up many essential topics with regard to future experimental studies - eg, knowledge of the degree of graphite dust exposure needed to expect fibrogenic effects and information on the particle size distribution, the mandatory use of control groups of animals in the experiments and blind reading of the pathological findings, ie, the pathologist should not know whether the animals belong to the experimental or control group.

Further experimental studies must be done to clarify whether analytically pure graphite can cause pneumoconiosis in adequately exposed animals.

There are 18 epidemiologic studies of 
workers exposed to graphite dust. Most of them are however invalid as epidemiologic studies because they do not comply with the ordinary requirements for study design. The prevalence rates of the studies vary greatly. The variation can probably be explained partly by differences in methodology and design and partly by real differences in prevalence rates. However, with two exceptions, the studies of employees in mines in Europe did not show a very wide prevalence range.

One might question whether mass miniature radiography provides the necessary validity in epidemiologic screening for pneumoconiosis. The answer might be no $(53,66$, JA Dick, National Coal Board, personal communication). The ILO standards for equipment, film quality, and reading (31) give an opportunity to compare the results of different studies. Because so various standards were applied in the 18 studies, the results cannot be compared directly.

The epidemiologic studies demonstrate that graphite pneumoconiosis has been a relatively frequent chronic lung disease among certain groups of graphite-exposed workers. The disease is probably less frequent today. The epidemiologic studies have not been suitable to illuminate any association between the degree of exposure to graphite dust and the prevalence of pneumoconiosis. The studies do not provide the necessary information to relate the reported prevalence rates to the silica content in graphite dust in different workplaces. But most of the studies state that graphite pneumoconiosis develops only after many years of exposure. There is still a need for well-designed epidemiologic studies which could help to establish the dose-response relationship between graphite dust with different quartz contents and pneumoconiosis.

This literature review shows that there are a few reports which suggest that pure or nearly pure graphite may cause graphite pneumoconiosis. The reports presented do not provide overwhelming evidence. Several reports demonstrate, as expected, that graphite dust mixed with a certain content of free silica may cause pneumoconiosis - a mixed-dust pneumoconiosis. The present state of knowledge does not exclude the possibility that ana- lytically pure graphite may cause pneumoconiosis. Free silica may not be necessary to develop graphite pneumoconiosis, but it may act as a modifier, promoting the development. The etiology and pathogenesis of graphite pneumoconiosis may be parallel to that of coal worker's pneumoconiosis.

\section{Acknowledgment}

Dr K Venables, TUC Centenary Institute of Occupational Health, London School of Hygiene and Tropical Medicine, has been my supervisor during my work with this review.

\section{References}

1. Battigelli MC. Experimental studies on the mechanism of pulmonary injury from air pollutants. J environ sci 13 (1970): 2, 25-27.

2. Bovet P. Die Wirkung von Graphit und anderen Kohlenstoffmodifikationen im Tierversuch; zugleich ein Beitrag zur experimentellen Silikoseforschung. Schweiz $Z$ Allg Pathol Bakteriol 15 (1952) 548-565.

3. Brauss FW. Röntgenologische Untersuchung über Graphiteinwirkung. Wiss Forschungsber (Darmstadt) 63 (1954) 312-313.

4. Bruusgaard A. En hygienisk undersøkelse av 83 grafittarbeidere. Nord hyg tid 18 (1937) 399-411.

5. Casalone E, Rasetti L. Rischio silicotigeno in operai esposti ad inalazioni di polvere di grafite. Med lav 54 (1963) 597-600.

6. Coscia GC, Gaido PC, Rasetti L. Quadri clinici e radiologici nei minatori della grafite. Med lav 54 (1963) 742-743.

7. Dassanayake WLP. The health of plumbago workers in Ceylon. $\mathrm{Br} \mathrm{j}$ ind med 5 (1948) $141-147$.

8. Drowatzky U. Die Beeinflussung der Quarzretention durch Inhalation von Graphit. Rheinisch-Westfälische Technische Hochschule Aachen, Aachen 1970. (Doctoral thesis).

9. Dunner L. Observations on pulmonary disease in graphite workers. $\mathrm{Br} \mathrm{j}$ radiol 18 (1945) $33-35$.

10. Dunner L. Observations on the development of graphite pneumoconiosis. $\mathrm{Br}$ radiol 21 (1948) 182-185.

11. Dunner L. Graphite pneumoconiosis. Lancet 2 (1949) 1054-1055.

12. Dunner L, Bagnall DJT. Graphite pneumoconiosis complicated by cavitation due to necrosis. $\mathrm{Br} \mathrm{j}$ radiol 19 (1946) $165-168$.

13. Dunner L, Bagnall DJT. Pneumoconiosis in graphite workers. Br j radiol 22 (1949) $573-579$.

14. Einbrodt HJ. Zur biologischen Schädigungsmöglichkeit durch die Kohlenstoffmodifikationen Koks und Graphit. Staub 33 (1973) $474-478$. 
15. Engelmann W. Beiträge zur Pathologie der Graphitstaublunge. Ludwig-Maximilian University, Munich 1954. (Doctoral thesis).

16. Faulkner WB. Bilateral pulmonary abscess secondary to pneumoconiosis. Dis chest 6 (1940) 306-308.

17. Foà V, Grieco A, Zedda S. Clinical and $X$-ray studies on the incidence of pneumoconiosis among carbon electrode makers [in Italian]. Med lav 57 (1966) 684-695.

18. Gaensler EA, Cadigan J, Sasahara A, Fox E, MacMahon H. Graphite pneumoconiosis of electrotypers. Am j med 41 (1966) 864882.

19. Gaido PC, Capellaro F, Braguzzi E, Parigi A, Rosettani E. Incidenza della silicosi nell' estrazione di talco e grafite. Arch sci med 116 (1963): 5, 227-233.

20. Glauser A, Rüttner JR. Über PseudoAsbestosekörperchen (sogenannte Karborund- und Graphitkörperchen). Experientia 7 (1951) 275-276.

21. Gloyne SR, Marshall G, Hoyle C. Pneumoconiosis due to graphite dust. Thorax 4 (1949) 31-38.

22. Gough J. Pneumoconiosis in coal trimmers. $J$ pathol bacteriol 51 (1940) 277-285

23. Güttner H-G. Pneumokoniose durch Graphitstaub. Zbl Allg Pathol Pathol Anat 90 (1953) $108-115$.

24. Haferland W. Graphitstaublunge und Silikose. Arch Gewerbepathol Gewerbehyg 16 (1957) 53-62.

25. Hanoa R. Health and work environment in a mining company: Investigations at Skaland Graphite Works Ltd [in Norwegian]. University of Troms $\varnothing$, Institute of Community Medicine, Troms $\emptyset 1981$.

26. Harding $\mathrm{HE}$, Oliver GB. Changes in the lungs produced by natural graphite. $\mathrm{Br} \mathrm{j}$ ind med 6 (1949) 91-99.

27. Heppleston AG. Graphite pneumoconiosis. Lancet 2 (1949) 960-961.

28. Hirsch M, Kass I, Schaefer W, Denst J. Infection with atypical tubercle bacilli in graphite pneumoconiosis. Arch intern med 103 (1959) 814-817.

29. Hollmann R. Über die Einwirkung von Kohlen- und Graphitstaub ohne Gesteins beimengung auf die Lunge. $\mathrm{Z}$ Tuberk 52 (1928) $394-396$.

30. Inoue A, Okazima $H$, Sawada $K$, et al. A case of graphite lung [in Japanese]. Jpn $\mathrm{j}$ chest dis 41 (1982): $1,58-63$.

31. International Labour Office. Guidelines for the use of ILO international classification of radiographs of pneumoconiosis. Geneva 1980. (Occupational safety and heal th series no 22).

32. Jacobsen M. Dust exposure and pneumoconiosis at 10 British coal mines. Paper presented at the ILO V th International Conference on Pneumoconiosis, Caracas 1978.

33. Jaffe FA. Graphite pneumoconiosis. Am j pathol 27 (1951) 909-923.

34. Kaestle C. Untersuchungen über den Einfluss der Beschäftigung in der bayerischen Graphitindustrie auf die Atmungsorgane der Arbeiter. Radiol Rundsch 1 (1932) 6773.
35. Koelsch F. Zur Frage der "Graphitstaublunge." Zbl Arbeitsmed Arbeitsschutz 8 (1958): 1-6, 31-35.

36. Koizumi $\mathrm{S}$, Oyamada $\mathrm{M}$, Mizuhara $\mathrm{H}$, Nagano $H$. Graphite pneumoconiosis with radiographic presentation of diffuse granular particles and nodules in the lung [in Japanese]. Jpn $j$ thorac dis 12 (1974) $273-$ 277.

37. Koopmann H. Beitrag zur Frage der Pneumokoniosen. Virchows Arch A: Pathol Anat 253 (1924) 423-431.

38. Koschnitsky IN, Krichkovsky G, Verbitskaya L, Lysenko N, Birbraer M, Alengov N, Lochmatov D, Jaroshuk A. Silicosis in graphite industry [in Russian]. Ter arkh 36 (1964): 8, 111-115.

39. Lister WB. Carbon pneumoconiosis in a synthetic graphite worker. $\mathrm{Br} \mathrm{j}$ ind med 18 (1961) 114-116.

40. Lister WB, Wimborne D. Carbon pneumoconiosis in a synthetic graphite worker. $\mathrm{Br}$ $j$ ind med 29 (1972) $108-110$.

41. Lochtkemper FJ, Teleky L. Die Staublunge in einzelnen besonderen Betrieben und bei besonderen Arbeiten. Arch Gewerbepathol Gewerbehyg 3 (1932) 600-672.

42. MacMahon HE. The application of X-ray diffraction in pathology (with particular reference to pulmonary graphitosis). Am j pathol 28 (1952) 531-532.

43. McCord CP. Graphite (plumbago, black lead), as a source of dusty lung disease. Ind med surg 18 (1949) 483-486.

44. Miller AA, Ramsden F. Carbon pneumoconiosis. Br $\mathrm{j}$ ind med 18 (1961) $103-113$.

45. Müller $\mathrm{H}$. Staublungenveränderungen bei Graphit-Arbeitern. Fortschr Geb Röntgenstr 76 (1952) 452-459.

46. Müller H. Zystenbildungen in GraphitStaublungen. Fortschr Geb Röntgenstr 79 (1953) 205-210.

47. Müller H. Kann Graphit Staublungenveränderungen hervorrufen? Aerztl Wochenschr 8 (1953): 2, 1226-1229.

48. Okutani H, Shima S, Sano T. Graphite pneumoconiosis in carbon electrode makers. In: Excerpta Medica Foundation. Proceedings of the XIVth international congress of occupational health, Madrid, 1963. Amsterdam 1964, pp 626-632. (International congress series no 62,2 ).

49. Osanai H, Sato K. Experimental studies on graphite pneumoconiosis [in Japanese]. J sci labour 34 (1958) 90-94.

50. Osanai H, Sato K. Experimentelle Untersuchungen über Staublungenerkrankungen durch Graphit. Staub 18 (1958) 328.

51. Otto H, Einbrodt HJ. Lungenstaubanalyse bei excessiver Anthrakose und ihre versicherungsrechtliche Bedeutung. Frankfurter Z Pathol 69 (1958) 404-415.

52. Ottowicz J, Paradowski Z. Investigations of the fibrogenic activity of industrial graphite dust [in Polish]. Postepy hig med dosw 15 (1961) $341-351$.

53. Parkes WR. Occupational lung disorders. Butterworths, London 1982.

54. Parmeggiani L. La pneumoconiosi da grafite. Rass med ind 18 (1949) 93-125.

55. Parmeggiani L. Graphite pneumoconiosis. 
$\mathrm{Br} \mathrm{j}$ ind med 7 (1950) $42-45$.

56. Pendergrass EP, Vorwald A, Mishkin M Whild in J, Werley C. Observations on workers in the graphite industry: Part One. Med radiogr photogr 43 (1967) 69-99.

57. Pendergrass EP, Vorwald A, Mishkin M, Whildin J, Werley C. Observations on workers in the graphite industry: Part Two. Med radiogr photogr 44 (1968) $2-17$.

58. Policard A, Rollet J. Etude expérimentale de l'action de diverses variétés de charbon sur le tissu conjonctif. Arch mal prof med trav secur soc 3 (1941): 1-2, 6-13.

59. Radionov AD, Zilenberg P, Geschel L. A trial to improve working conditions in a curing fabric of the Zavalevski graphite combinate [in Russian]. Gig tr prof zabol 11 (1967): 8, 57-58.

60. Ranasinha KW, Uragoda CG. Graphite pneumoconiosis. $\mathrm{Br} \mathrm{j}$ ind med 29 (1972) $178-183$.

61. Ray SC, King EJ, Harris on CV. The action of small amounts of quartz and larger amounts of coal and graphite on the lungs of rats. $\mathrm{Br} \mathrm{j}$ ind med 8 (1951) $68-73$.

62. Rüttner JR. Über Asbestose- und Pseudoasbestosekörperchen. Schweiz Z Allg Pathol Bakteriol 15 (1952) 628-631.

63. Rüttner JR, Bovet $P$, Aufdermaur $M$. Graphit, Carborund, Staublunge. Dtsch med Wochenschr 77 (1952) 1413-1414.

64. Rüttner JR, Bovet P, Weber R, Willy W. Neue Ergebnisse tierexperimenteller Silikoseforschung. Naturwissenschaften 39 (1952) 332

65. Schkavro VG. Graphite dust in iron metallurgy [in Russian]. Gig sanit 32 (1967): 2, 106-107.

66. Sheers G, Rossiter C, Gilson J, Mackenzie F. UK naval dockyards asbestosis study: Radiological methods in the surveillance of workers exposed to asbestos. $\mathrm{Br} \mathrm{j}$ ind med
35 (1978) 195-203.

67. Sklensky B, Berka I. Pneumoconiosis in the graphite mines [in Czech]. Prac lek 15 (1963) 422-426.

68. Town JD. Pseudoasbestos bodies and asteroid giant cells in a patient with graphite pneumoconiosis. Can med ass oc j 98 (1968) 100-104.

69. Uragoda CG. Pulmonary tuberculosis in graphite miners. J trop med hyg 75 (1972) $217-220$.

70. Uragoda CG. Graphite pneumoconiosis complicated by tuberculosis. Ceylon med $\mathrm{j}$ 17 (1972) 168-170.

71. Uragoda CG, Rajendra M. Pneumoconiosis in graphite curers. Indian $\mathrm{j}$ ind med 21 (1975): $3,105-113$.

72. Walton WH, Dodgson J, Haddon G, Jacobsen $M$. The effect of quartz and other non-coal dusts in coal worker's pneumoconiosis: Part I Epidemiological studies. In: Walton WH, ed. Inhaled particles IV. Pergamon Press, Oxford 1977, pp 669700.

73. Watson A, Black J, Doig A, Nagelschmidt G. Pneumoconiosis in carbon electrode makers. $\mathrm{Br} \mathrm{j}$ ind med 16 (1959) 274-285.

74. Zahorski W. Pneumoconiosis in workers of artificial graphite plants [in Polish]. Med pr 11 (1960): 5, 383-386.

75. Zahorski W, Potoska-Skowronek Z, Pierzchala W. Pneumoconiosis in persons engaged in the production of carbon electrodes [in Polish]. Med pr 26 (1975) 1-8.

76. cet 2 (1949) 519. (Editorial).

77. - - Suspected pneumoconiosis of graphite workers. Br med j 1 (1945) 916. (Editorial).

Received for publication: 5 April 1983 